\title{
Correction: Socioeconomic position and use of healthcare in the last year of life: A systematic review and meta-analysis
}

\author{
Joanna M. Davies, Katherine E. Sleeman, Javiera Leniz, Rebecca Wilson, Irene \\ J. Higginson, Julia Verne, Matthew Maddocks, Fliss E. M. Murtagh
}

Reference numbers 96 and 118 in the manuscript appear incorrectly, due to reference formatting software errors. They should appear as below:

96. Dixon J, King D, Matosevic T, Clark M, Knapp M. (2015). Equity in Provision of Palliative Care in the UK. Marie Curie: London.

118. Mayhew L, Rickayzen B, Smith D. (2017). Does living in a retirement village extend life expectancy? The case of Whiteley Village. The International Longevity Centre UK: London.

\section{Reference}

1. Davies JM, Sleeman KE, Leniz J, Wilson R, Higginson IJ, Verne J, et al. (2019) Socioeconomic position and use of healthcare in the last year of life: A systematic review and meta-analysis. PLoS Med 16(4): e1002782. https://doi.org/10.1371/journal.pmed.1002782 PMID: 31013279

\section{G OPEnACCESS}

Citation: Davies JM, Sleeman KE, Leniz J, Wilson R, Higginson IJ, Verne J, et al. (2019) Correction: Socioeconomic position and use of healthcare in the last year of life: A systematic review and metaanalysis. PLoS Med 16(7): e1002878. https://doi. org/10.1371/journal.pmed.1002878

Published: July 18, 2019

Copyright: ๑ 2019 Davies et al. This is an open access article distributed under the terms of the Creative Commons Attribution License, which permits unrestricted use, distribution, and reproduction in any medium, provided the original author and source are credited. 